\title{
Purification and characterization of $S$ layer proteins from Clostridium difficile GAI 0714
}

\author{
Aya Takeoka, Kenji Takumi, ${ }^{*}$ Tetsuro Koga and Tomio Kawata \\ Department of Food Microbiology, Tokushima University School of Medicine, Tokushima 770, Japan
}

(Received 25 June 1990; revised 19 September 1990; accepted 27 September 1990)

\begin{abstract}
The S layer of Clostridium difficile GAI 0714 was shown to be composed of two proteins, of $32 \mathrm{kDa}$ and $45 \mathrm{kDa}$, as determined by SDS-PAGE. The two proteins were extracted with $8 \mathrm{M}$-urea (pH 8-3) from a cell wall preparation and purified by DEAE-Sepharose CL-6B chromatography followed by HPLC gel filtration. When solubilized in 0.1 M-urea, both proteins appeared to exhibit dimeric forms, with respective molecular masses of about $61 \mathrm{kDa}$ and $99 \mathrm{kDa}$, upon HPLC. Although the amino acid compositions of the two proteins differed from each other, both proteins had a high content of acidic amino acids, very low contents of histidine and methionine, and no cysteine. The $32 \mathrm{kDa}$ protein exhibited multiple isoelectric forms (pI 3.7-3.9), whereas the $45 \mathrm{kDa}$ protein had a single form (pI 3.3). Radioiodination and immunogold labelling revealed that both proteins were exposed evenly over the entire cell surface. Based on immunodiffusion analysis using monospecific antiserum raised to the individual proteins, there was no antigenic relationship between the two proteins. Furthermore, immunoblot analysis showed that the antigenicity of the $32 \mathrm{kDa}$ protein appeared to be strain specific, whereas that of the $45 \mathrm{kDa}$ protein appeared to be group specific.
\end{abstract}

\section{Introduction}

Crystalline surface layers (S layers) (Sleytr \& Messner, 1988) or paracrystalline protein surface arrays (Koval, 1983) are present on the cell surface of various bacteria, including Gram-positive and Gram-negative bacteria and archaeobacteria. Most $\mathrm{S}$ layers are composed of a single protein or glycoprotein species of molecular mass about 40-200 kDa (Sleytr \& Messner, 1983). The subunit proteins are noncovalently attached either to each other or to underlying cell wall components and they represent the primary barrier between the cells and the environment (Sleytr \& Messner, 1983).

Clostridium difficile, an important pathogen causing human pseudomembranous colitis, has a squarely arranged $\mathrm{S}$ layer composed of two proteins with different molecular masses (Kawata et al., 1984). On the basis of the molecular mass values of the two proteins, $C$. difficile strains are divided into two groups: group 1, containing about 32 and $45-47 \mathrm{kDa}$ proteins; and group 2, containing about 38 and $42 \mathrm{kDa}$ proteins. The $32 \mathrm{kDa}$ protein of the $\mathrm{S}$ layer of $C$. difficile ATCC 11011 (group 1) has been purified and characterized immunochemically; the protein was extracted with phosphate-buffered saline (PBS) from the cell walls without the use of detergents or chaotropic agents such as urea or guanidine hydro- chloride (Takumi et al., 1987). The $45 \mathrm{kDa}$ protein, however, was not detected in the PBS extract but was solubilized using higher molar concentrations of urea.

The aim of the present work was to gain an understanding of the immunological relationship between the constituent protein subunits $(32 \mathrm{kDa}$ and $45 \mathrm{kDa}$ ) of the $\mathrm{S}$ layer of $C$. difficile. These proteins from C. difficile strain GAI 0714 were purified and characterized immunochemically. Immunoelectron microscopy also revealed that both the $S$ layer proteins were evenly exposed on the cell surface.

\section{Methods}

Bacterial strains and cultivation. C. difficile GAI 0714, which was isolated from a patient with antibiotic-associated pseudomembranous colitis, was the main strain used. Other strains used are listed in the legend to Fig. 8. Bacteria were grown anaerobically in GYPT medium at $37^{\circ} \mathrm{C}$ as described previously (Kawata et al., 1984).

Preparation of cell walls. Cell walls were isolated from cells harvested from a $10 \mathrm{~h}$ culture (early stationary phase) as described previously (Kawata et al., 1984). Briefly, the cells were washed with cold water and broken in a Braun MSK cell homogenizer. Unbroken cells were removed by low-speed centrifugation, then the wall fragments were separated from the supernatant by centrifugation $(18000 \mathrm{~g}, 15 \mathrm{~min})$ and washed sequentially with $1 \mathrm{M}-\mathrm{NaCl}, 2 \%(\mathrm{w} / \mathrm{v})$ Triton $\mathrm{X}-100$ and cold water to remove membranous contaminants. The resulting cell wall pellet was stored at $4{ }^{\circ} \mathrm{C}$ in water containing $0.02 \%(w / v) \mathrm{NaN}_{3}$ and $2 \mathrm{mM}$-phenylmethylsulphonyl fluoride (PMSF, Sigma). 
Purification of 32 and $45 k$ Da proteins. All the buffer solutions used in this procedure contained $2 \mathrm{mM}$-PMSF. The cell wall preparation was suspended in $50 \mathrm{~mm}$-Tris/ $\mathrm{HCl}$ buffer (pH 8.3) containing $8 \mathrm{M}$-urea, stirred at room temperature for $1 \mathrm{~h}$ and centrifuged at $100000 \mathrm{~g}$ for $30 \mathrm{~min}$. This procedure was repeated on the pellet. The combined supernatants were concentrated to about half the original volume by an Amicon diafilter with a YM10 filter. The concentrate was applied to a column $(2.5 \times 30 \mathrm{~cm})$ of DEAE-Sepharose CL-6B (Pharmacia) equilibrated with the urea buffer. The column was washed with the same buffer, then the bound materials were eluted with a linear gradient of $0-0 \cdot 3 \mathrm{M}-\mathrm{NaCl}$ in the buffer at a flow rate of $20 \mathrm{ml} \mathrm{h}^{-1}$. Fractions of $5 \mathrm{ml}$ were collected, monitored at $280 \mathrm{~nm}$ for protein, and analysed by SDSPAGE. The 32 and $45 \mathrm{kDa}$ protein fractions were pooled and concentrated, and chromatography on the anion-exchange column was repeated under the same conditions as above. The two protein fractions were separately subjected to HPLC with a Hitachi instrument and a TSK G3000SW column $(7.5 \mathrm{~mm}$ i.d. $\times 60 \mathrm{~cm}$; Tosoh Co., Tokyo, Japan) equilibrated with 20 mM-PBS containing 0.1 m-urea. The HPLC column was eluted at a flow rate of $0.8 \mathrm{ml} \mathrm{min}^{-1}$ with the PBS. Fractions of $0.3 \mathrm{ml}$ were collected, assayed for protein content, and stored at $-20^{\circ} \mathrm{C}$. Each final preparation gave a single protein band on SDS-PAGE.

$S D S-P A G E$. SDS-PAGE was performed according to the method of Laemmli (1970), using a separating gel of $12 \%$ (w/v) acrylamide as described previously (Takumi et al., 1987). Proteins bands were visualized by staining with Coomassie Brilliant Blue R250. Apparent molecular masses were calculated by comparison with standards from a low molecular mass protein kit (Pharmacia).

Chemical analyses. The protein concentration was determined by the Lowry method, with bovine serum albumin as standard. Amino acids were analysed on a Hitachi KLA-5 amino acid analyser after hydrolysis of purified wall proteins in $6 \mathrm{M}-\mathrm{HCl}$ at $110^{\circ} \mathrm{C}$ for $24 \mathrm{~h}$ as described previously (Takumi et al., 1987).

Determination of molecular mass by HPLC. Molecular weights of the undenatured forms of the purified $S$ layer proteins were estimated by HPLC on a G3000SW column, eluted with PBS containing 0.1 M-urea. The molecular masses were determined by comparison with molecular mass standards for gel filtration chromatography (Sigma) including $\beta$ galactosidase $(116 \mathrm{kDa})$, phosphorylase $b(94 \mathrm{kDa})$, bovine serum albumin $(67 \mathrm{kDa})$, ovalbumin $(43 \mathrm{kDa})$ and carbonic anhydrase $(30 \mathrm{kDa})$.

Isoelectric focusing. The isoelectric points (pIs) of the purified $\mathrm{S}$ layer proteins were determined with a horizontal electrophoretic apparatus (model AF-3230, Atto Ltd, Tokyo, Japan) on $5 \%(w / v)$ acrylamide gels using Pharmalyte 2.5-5 (Pharmacia). Focusing was performed for $2 \mathrm{~h}$ at $1500 \mathrm{~V}$ and the focused protein bands were revealed with Coomassie Brilliant Blue. The pIs were estimated by determining the relative mobility of the proteins compared with pI marker proteins (LKB Instruments).

Peptide mapping. Peptide mapping of purified S layer proteins was performed after limited proteolysis with $10 \mathrm{ng}$ staphylococcal V8 protease (Miles Laboratories) according to the method of Cleveland $e t$ al. (1977), using gel pieces containing 30-50 $\mu \mathrm{g}$ S layer protein, which had been obtained from the gel after SDS-PAGE of the purified proteins, and a separating gel with a $15-20 \%(w / v)$ linear gradient of acrylamide.

Iodination with ${ }^{125} \mathrm{INa}$. Radioiodination using chloramine $\mathrm{T}$ was carried out essentially according to the method of Nesbitt et al. (1980). Whole cells were suspended in $6 \mathrm{ml} 0.5 \mathrm{M}$-sodium phosphate buffer ( $\mathrm{pH} 7.5$ ), and mixed with $25 \mu \mathrm{l}$ sodium iodate containing ${ }^{125} \mathrm{INa}$ $(50 \mu \mathrm{Ci} ; 1850 \mathrm{kBq})$ with vigorous stirring for $10 \mathrm{~min}$ at room temperature. The reaction mixture was added to $1 \mathrm{ml}$ chloramine $\mathrm{T}$
( $\left.2.0 \mathrm{mg} \mathrm{ml}^{-1}\right)$ in $0.5 \mathrm{M}$-sodium phosphate buffer $(\mathrm{pH} \mathrm{7.5)}$ and stirred for $3 \mathrm{~min}$. The iodination was stopped by adding $1 \mathrm{ml}$ sodium metabisulphite $\left(4 \mathrm{mg} \mathrm{ml}^{-1}\right)$. The labelled cells were washed three times with the phosphate buffer, then the cell wall fraction was prepared from the disrupted cells and subjected to SDS-PAGE. The proteins were identified by autoradiography of the gels at $4{ }^{\circ} \mathrm{C}$ for $3 \mathrm{~d}$ using Kodak XOmat RP film with Cronex intensifying screens (Dupont de Nemours).

Preparation of antisera and immunological assays. For immunization, purified $S$ layer protein preparations were freed from detergent by ethanol precipitation, dissolved in PBS and emulsified in an equal volume of Freund's complete adjuvant. Rabbits were injected subcutaneously with $1 \mathrm{mg}$ of the protein preparation at several sites on the back. After 2 or 3 weeks, the animals were injected in the same manner with $1 \mathrm{mg}$ of the protein emulsified in incomplete Freund's adjuvant; they were bled 2 weeks later.

Immunodiffusion was carried out with $0.8 \%(w / v)$ agarose gels in barbital buffer (pH 8.6) as described previously (Takumi et al., 1983).

Western blotting was done by the electrophoretic transfer procedure of Towbin et al. (1979) using a Bio-Rad Immun-Blot assay kit as described previously (Takumi et al., 1987).

Preparation of protein A-colloidal gold conjugate. Colloidal gold particles with an average diameter of 5-7 nm were prepared by the procedure of Mülhpfordt (1982). Chloroauric acid was reduced with a mixture of $1 \%(w / v)$ sodium citrate and $1 \%(w / v)$ tannic acid. The gold particles were adsorbed with protein A (Pharmacia) to produce a stable colloidal suspension of protein A-gold conjugate according to the method of Roth et al. (1978). The conjugate was suspended in a small volume of $20 \mathrm{~mm}$-phosphate buffer ( $\mathrm{pH} \mathrm{7.4)}$ containing $0.02 \%(\mathrm{v} / \mathrm{v})$ polyethylene glycol and $0.02 \%(\mathrm{w} / \mathrm{v})$ sodium azide, and stored at $4{ }^{\circ} \mathrm{C}$.

Immunoelectron microscopy. Whole cells of $C$. difficile $\mathrm{GAI} 0714$ were incubated with a $1: 10$ dilution of 32 or $45 \mathrm{kDa}$ protein antiserum in PBS containing $1 \%(\mathrm{w} / \mathrm{v})$ ovalbumin (Sigma) for $1 \mathrm{~h}$ at $4{ }^{\circ} \mathrm{C}$. After three washes with PBS, the cells were reincubated with the protein A-gold conjugate for $1 \mathrm{~h}$ at $4{ }^{\circ} \mathrm{C}$. The gold-labelled cells were prefixed with glutaraldehyde, fixed with osmium tetroxide, embedded in styrene/ methacrylate and cut with glass knives as described previously (Takumi et al., 1979). Thin sections were poststained wtih $0 \cdot 2 \%(\mathrm{w} / \mathrm{v})$ lead citrate and examined with a Hitachi HU-11E electron microscope operating at $75 \mathrm{kV}$.

\section{Results}

\section{Purification of two $S$ layer proteins}

To isolate and purify the two $\mathrm{S}$ layer proteins from $C$. difficile GAI 0714, cell wall preparations were extracted with Tris buffer containing $8 \mathrm{M}$-urea; by this method both the $45 \mathrm{kDa}$ protein and the $32 \mathrm{kDa}$ protein could be removed from the cell walls. The urea extract was fractionated on a DEAE-Sepharose CL-6B column with a linear concentration gradient of $\mathrm{NaCl}$ (Fig. 1). Fractions containing the 32 and $45 \mathrm{kDa}$ proteins, each showing a single protein band on SDS-PAGE, were eluted around 0.13 and $0.21 \mathrm{M}-\mathrm{NaCl}$, respectively. Further separation of the two proteins was achieved by repeated chromatography on the same anion-exchange resin. Each protein fraction was finally purified by HPLC gel filtration, eluting with $0.1 \mathrm{M}$-urea in PBS. The 32 and $45 \mathrm{kDa}$ proteins were eluted as single sharp peaks 


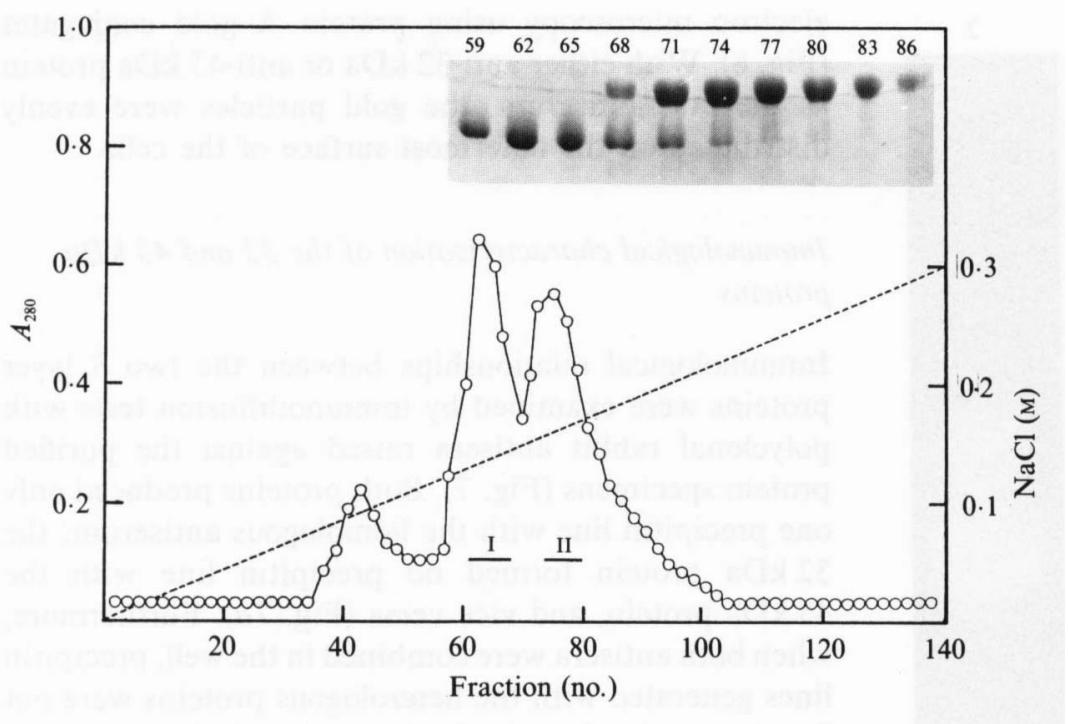

Fraction (no.)
Fig. 1. Separation of S layer proteins from C. difficile GAI 0714 on a DEAE-Sepharose CL-6B column. Concentrated $8 \mathrm{M}$-urea-extracted $\mathrm{S}$ layer proteins were chromatographed on a $3 \mathrm{~cm} \times 30 \mathrm{~cm}$ column with a linear gradient of $0-0.3 \mathrm{M}-\mathrm{NaCl}$ in $50 \mathrm{~mm}$ Tris/ $\mathrm{HCl}$ buffer ( $\mathrm{pH} 8 \cdot 3$ ) containing $8 \mathrm{M}$-urea; $5 \mathrm{ml}$ fractions were collected. The bars (I and II) indicate the pooled fractions. Inset: SDS-PAGE profiles of fractions along the column; $50 \mu \mathrm{l}$ samples of fractions were applied to the gel; numbers signify the corresponding column fractions.
Table 1. Amino acid composition of $32 \mathrm{kDa}$ and $45 \mathrm{kDa}$ proteins

\begin{tabular}{lcc}
\hline \hline & \multicolumn{2}{c}{ Mol $\%$} \\
\cline { 2 - 3 } Constituent & $32 \mathrm{kDa}$ & $45 \mathrm{kDa}$ \\
\hline Asp & 13.3 & 16.0 \\
Thr & 6.6 & 4.0 \\
Ser & $8 \cdot 8$ & 11.2 \\
Glu & $10 \cdot 0$ & 9.0 \\
Pro & 3.7 & 0.5 \\
Gly & $7 \cdot 3$ & 8.0 \\
Ala & 9.5 & 10.2 \\
Val & $7 \cdot 7$ & 7.2 \\
Cys (half) & 0 & 0 \\
Met & 1.4 & 1.5 \\
Ile & 4.8 & 5.2 \\
Leu & 7.0 & 8.9 \\
Tyr & 4.5 & 2.5 \\
Phe & 2.7 & 2.4 \\
Lys & 10.0 & 9.8 \\
His & 0.5 & 0.5 \\
Arg & 1.9 & 2.0 \\
Amino acid type: & & \\
Acidic & 23.3 & 25.0 \\
Basic & 12.4 & 12.5 \\
Hydrophobic & 36.8 & 36.9 \\
\hline \hline
\end{tabular}

at retention times of 12.5 and $16.2 \mathrm{~min}$, respectively (not shown). The purity of the two proteins thus obtained was also estimated to be highly homogeneous by SDS-PAGE and the respective apparent molecular masses of their monomeric forms were confirmed to be 32 and $45 \mathrm{kDa}$ (Fig. 2). When the molecular masses of the 32 and $45 \mathrm{kDa}$ proteins were determined by comparison with marker proteins on HPLC gel filtration, they appeared to be 61 and $99 \mathrm{kDa}$, respectively, suggesting that the two proteins exhibit dimeric forms in such a low concentration of urea (not shown).

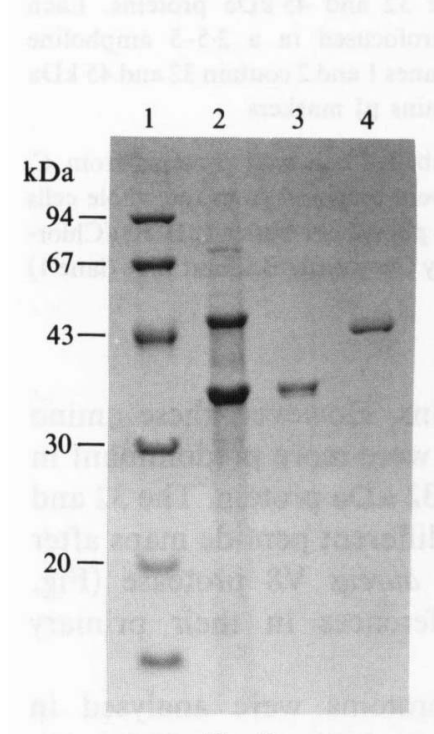

Fig. 2

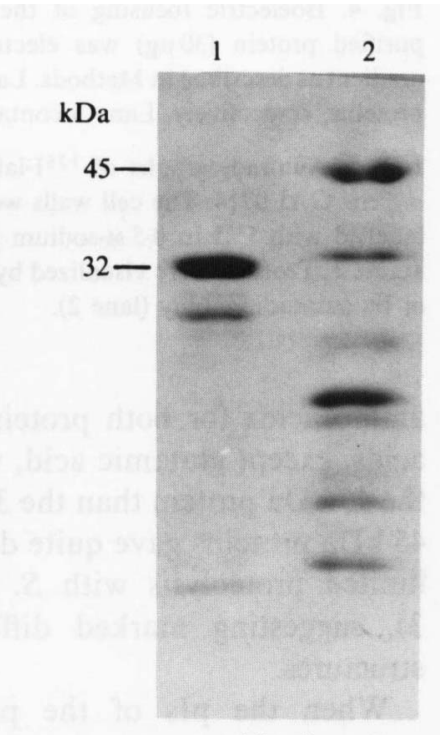

Fig. 3
Fig. 2. SDS-PAGE profiles of the 32 and $45 \mathrm{kDa}$ proteins purified by G3000SW HPLC. Each protein $(20 \mu \mathrm{g})$ was electrophoresed through a $12 \%(\mathrm{w} / \mathrm{v})$ polyacrylamide gel. Lanes: 1 , molecular mass markers; 2 , $8 \mathrm{M}$-urea extract; 3 and 4, purified 32 and $45 \mathrm{kDa}$ proteins, respectively.

Fig. 3. Peptide maps of the 32 and $45 \mathrm{kDa}$ proteins. Purified proteins were digested with Staphylococcus V8 enzyme as described in Methods and run on $15-20 \%$ polyacrylamide gradient gels. Lanes 1 and 2 contain 32 and $45 \mathrm{kDa}$ proteins, respectively.

\section{Chemical characterization of the 32 and $45 k$ Da proteins}

Although both proteins had more acidic amino acid residues than basic ones, and also contained similar amounts of hydrophobic amino acids (about $37 \mathrm{~mol} \%$ ), the proteins differed in their contents of individual amino acids (Table 1). Aspartic acid, glutamic acid, serine, lysine, alanine, glycine, and valine were the major 


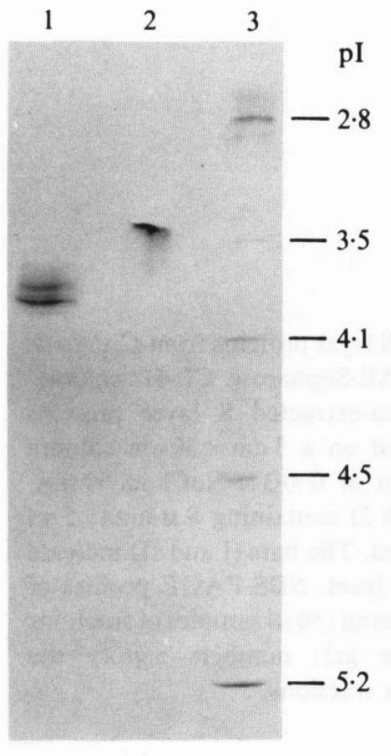

Fig. 4

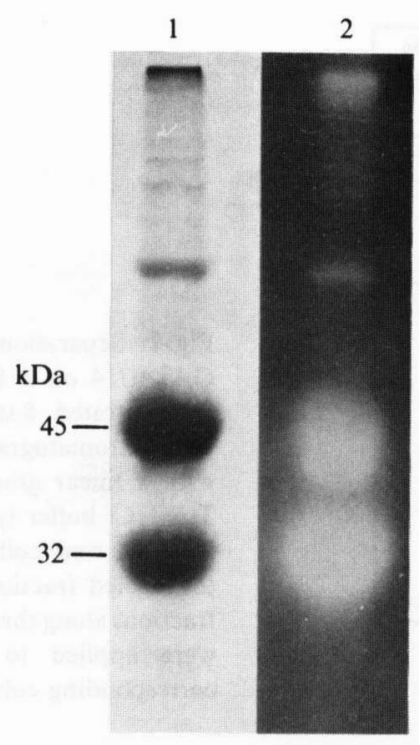

Fig. 5
Fig. 4. Isoelectric focusing of the 32 and $45 \mathrm{kDa}$ proteins. Each purified protein $(30 \mu \mathrm{g})$ was electrofocused in a $2 \cdot 5-5$ ampholine gradient as described in Methods. Lanes 1 and 2 contain 32 and $45 \mathrm{kDa}$ proteins, respectively. Lane 3 contains pI markers.

Fig. 5. Autoradiographs of ${ }^{125}$ I-labelled cell wall proteins from $C$. difficile GAI 0714. The cell walls were prepared from the whole cells labelled with ${ }^{125} \mathrm{I}$ in $0.5 \mathrm{M}$-sodium phosphate buffer ( $\mathrm{pH} \mathrm{7.5)/Chlor-}$ amine T. Proteins were visualized by Coomassie Brilliant Blue (lane 1) or by autoradiography (lane 2 ).

amino acids for both proteins. However, these amino acids, except glutamic acid, were more predominant in the $45 \mathrm{kDa}$ protein than the $32 \mathrm{kDa}$ protein. The 32 and $45 \mathrm{kDa}$ proteins gave quite different peptide maps after limited proteolysis with $S$. aureus V8 protease (Fig. 3 ), suggesting marked differences in their primary structures.

When the pIs of the proteins were analysed in polyacrylamide gels using ampholines of $\mathrm{pH} 2 \cdot 6-4 \cdot 0$, multiple isoelectric forms of pI 3.7-3.9 were obtained for the $32 \mathrm{kDa}$ protein, while a single form of pI 3.3 was found for the $45 \mathrm{kDa}$ protein (Fig. 4). These pI values were consistent with the acidic nature of the two $\mathrm{S}$ layer proteins.

\section{Surface exposure of the 32 and $45 \mathrm{kDa}$ proteins}

To determine if the two proteins were exposed on intact whole cells, cells were surface labelled with ${ }^{125}$ I. The isolated cell walls from the previously labelled cells were analysed by SDS-PAGE followed by autoradiography (Fig. 5). The 32 and $45 \mathrm{kDa}$ protein bands seen on SDSPAGE were labelled to a very similar extent by iodination, indicating the surface exposure of both proteins. This was further determined by immuno- electron microscopy using protein A-gold conjugates (Fig. 6). With either anti-32 kDa or anti-45 kDa protein as the first antiserum, the gold particles were evenly distributed on the outermost surface of the cells.

\section{Immunological characterization of the 32 and $45 \mathrm{kDa}$ proteins}

Immunological relationships between the two $S$ layer proteins were examined by immunodiffusion tests with polyclonal rabbit antisera raised against the purified protein specimens (Fig. 7). Both proteins produced only one precipitin line with the homologous antiserum; the $32 \mathrm{kDa}$ protein formed no precipitin line with the $45 \mathrm{kDa}$ protein, and vice versa (Fig. 7a). Furthermore, when both antisera were combined in the well, precipitin lines generated with the heterologous proteins were not fused to each other, indicating antigenic heterogeneity between the two proteins (Fig. $7 b$ ).

The $8 \mathrm{M}$-urea extracts from the cell walls of nine strains of $C$. difficile belonging to group 1 were assayed by immunoblotting with either anti-32 kDa or anti-45 kDa protein antiserum. SDS-PAGE profiles of the cell wall proteins revealed that all the strains tested contained two major protein bands corresponding to the 32 and $45 \mathrm{kDa}$ proteins (Fig. 8a). Only strain GAI 0714 had a protein that reacted with the anti- $32 \mathrm{kDa}$ protein antiserum, whereas seven of the nine strains had a protein that reacted with the anti- $45 \mathrm{kDa}$ protein antiserum (Fig. $8 b, c)$.

\section{Discussion}

In our previous work (Takumi et al., 1987), a $32 \mathrm{kDa}$ protein antigen from $C$. difficile ATCC 11011 was solubilized with PBS without the use of detergent or chaotropic agents, but the $45 \mathrm{kDa}$ protein was insoluble in PBS. In the present work, the $45 \mathrm{kDa}$ protein as well as the $32 \mathrm{kDa}$ protein were extracted from the cell walls by treatment with $8 \mathrm{M}$-urea in Tris buffer. $\mathrm{S}$ layer subunits are generally linked to the under-wall layer by differing combinations of hydrophobic bonds, ionic bonds and hydrogen bonds (Sleytr \& Messner, 1983). Perhaps the linkage of the $45 \mathrm{kDa}$ protein to the under-wall layer was stronger than, or different from, that of the $32 \mathrm{kDa}$ protein.

On HPLC gel filtration with $0 \cdot 1 \mathrm{M}$-urea in PBS, the $32 \mathrm{kDa}$ and $45 \mathrm{kDa}$ proteins were eluted with apparent molecular masses of 61 and $99 \mathrm{kDa}$, respectively, suggesting that the two proteins maintain a dimeric molecular form under these mild conditions. A similar dimeric form of S layer protein was observed for the A protein of Aeromonas salmonicida eluted by HPLC in the 

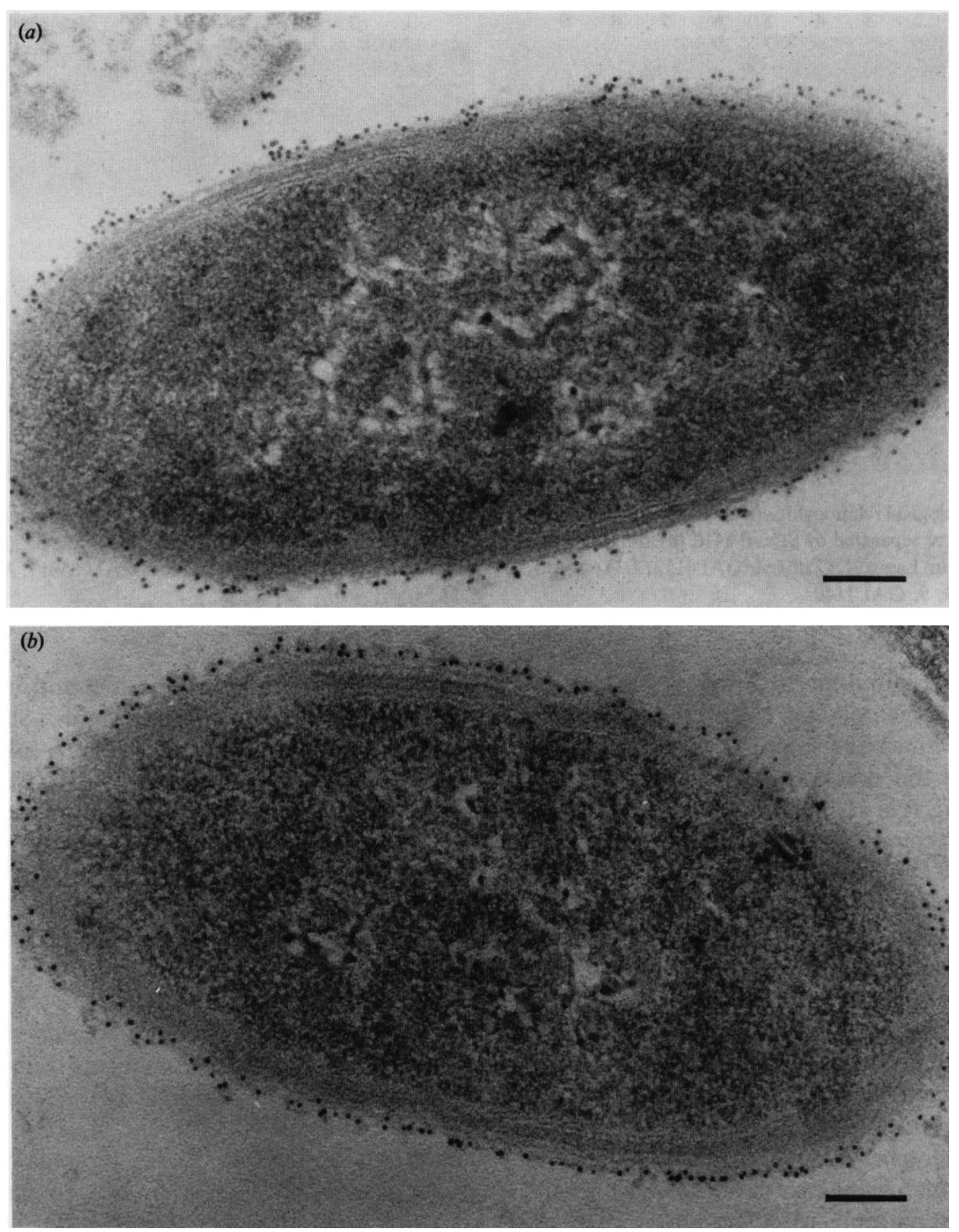

Fig. 6. Electron micrographs of thin sections from cells of $C$. difficile GAI 0714 prepared by reaction with rabbit antisera raised against the $32 \mathrm{kDa}(a)$ or $45 \mathrm{kDa}(b)$ protein followed by protein A-gold conjugate. Bars, $100 \mathrm{~nm}$.
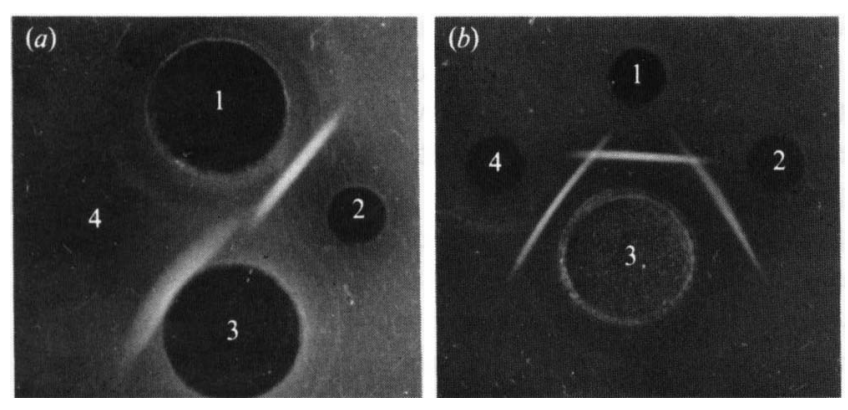

absence of detergent (Phipps et al., 1983). With the A protein, however, only a proportion of the protein was present in dimeric form. In contrast, all the monomeric subunits of each of the two proteins of $C$. difficile were

Fig. 7. Immunodiffusion analysis of the 32 and $45 \mathrm{kDa}$ proteins against their respective antisera. (a) Wells 1 and 3 contain anti-32 and $-45 \mathrm{kDa}$ protein antisera, respectively. Wells 2 and 4 contain 32 and $45 \mathrm{kDa}$ proteins, respectively. (b) Well 1 contains $32 \mathrm{kDa}$ protein; wells 2 and 4 contain $45 \mathrm{kDa}$ protein. Well 3 contains the two antisera combined in an equal volume. 

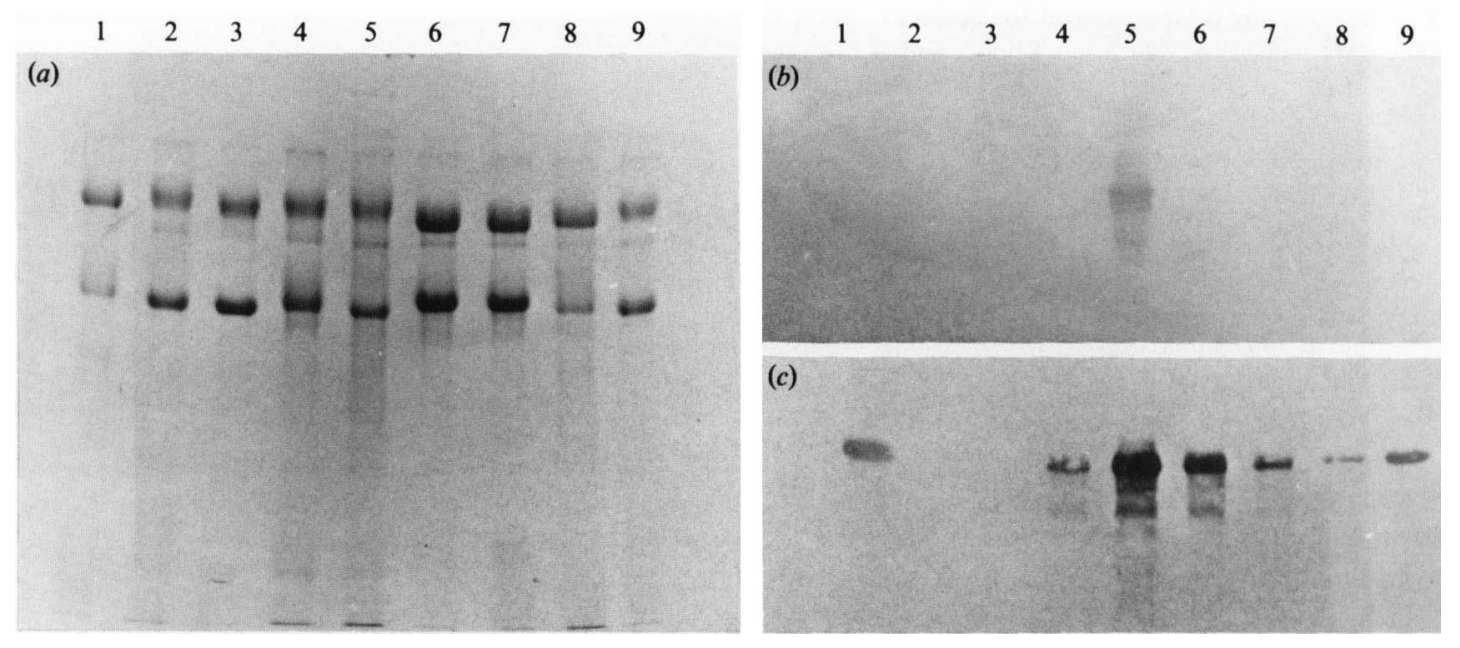

Fig. 8. Immunological relationships between the 32 and $45 \mathrm{kDa}$ proteins from group 1 strains of $C$. difficile. The $8 \mathrm{M}$-urea extracts from the cell walls were separated by SDS-PAGE $(a)$ and the immunoblots were performed with antiserum raised to the $32 \mathrm{kDa}(b)$ or the $45 \mathrm{kDa}(c)$ protein. Lanes: 1 , C. difficile GAI 41 32; 2, GAI 5415; 3, GAI 5416; 4, GAI 0284; 5, GAI 0714; 6, GAI 0858; 7, ATCC 11011 ; 8, ATCC 17859; 9, GAI 1140.

apparently converted into dimeric form, suggesting the presence of hydrophobic domains within the individual protein molecules. Since the mobility of the proteins in SDS-PAGE gels did not change when 2-mercaptoethanol was omitted, it is unlikely that the formation of disulphide bonds accounts for the increased molecular mass. Moreover, the amino acid analysis revealed a lack of cysteine residues.

The amino acid compositions of the 32 and $45 \mathrm{kDa}$ proteins were very similar to each other in respect of the distinctive features of S layer proteins (Kandler \& Konig, 1985; Sleytr et al., 1986; Bingle et al., 1986; Koval, 1988), which have a high proportion of nonpolar and acidic amino acids, a low content of sulphur-containing amino acids, and usually a lack of cysteine residues. The acidic nature of the two proteins may contribute to their low isoelectric points, which in the case of the $32 \mathrm{kDa}$ protein was represented by multiple pIs. The appearance of multiple of $\mathrm{pI}$ forms is not unusual for cell-surfacelocalized proteins (Russell, 1979; Phipps et al., 1983; Bingle et al., 1986). Multiple pI forms were also found for the intact cell surface protein of Micrococcus radiodurans (Baumeister et al., 1982), suggesting that their appearance is not connected with the purification procedure. The 32 and $45 \mathrm{kDa}$ proteins differed in the peptide maps generated by treatment with the V8 enzyme. No common peptide band was observed in the peptide fragments on SDS-PAGE. This chemical heterogeneity may account for the antigenic dissimilarity between the two antigens: no immunological cross-reaction between them was observed by immunodiffusion tests or immunoblot analyses. Antigenicity of the $32 \mathrm{kDa}$ protein was apparently strain specific, whereas a protein cross- reacting with anti- $45 \mathrm{kDa}$ protein antiserum was rather common among $C$. difficile strains. Sharp \& Poxton (1988) reported that the $6 \mathrm{M}$-urea-soluble antigenic proteins from various strains of $C$. difficile were apparently strain specific, although these antigens were highly variable in the molecular mass. In contrast, we demonstrated that the $C$. difficile strains tested could be divided into two groups on the basis of the molecular masses of the 6M-urea-extractable wall proteins (Kawata et al., 1984). For a solution to this discrepancy, more $C$. difficile strains must be examined.

Daily \& Schloemer (1988) reported the cloning and expression of two secreted antigens from $C$. difficile VPI 10463 in Escherichia coli RR1 M15. These two antigens were proteins of $32 \mathrm{kDa}$ and $43 \mathrm{kDa}$, and probably correspond to the two $\mathrm{S}$ layer proteins described here.

We confirmed that both the 32 and the $45 \mathrm{kDa}$ proteins were exposed on the cell surface by radioiodination and by immunoelectron microscopy using a protein A-gold conjugate. Since both proteins are essential constituents of the $S$ layer of the organism, it can be said that the $\mathrm{S}$ layer is a single macromolecular layer composed of two distinct protein species, which are exposed almost evenly on the outermost cell surface. Most bacterial $\mathrm{S}$ layers are composed of a single subunit (Sleytr \& Messner, 1983; Koval, 1988). Although the cell surface layer proteins isolated from Bacillus brevis 47 possess two protein subunits, this can be attributed to the presence of two distinct superimposed layers (Tsuboi $e t$ al., 1982). Thus the $S$ layer of $C$. difficile has a unique surface layer structure and it may therefore represent a model for a new type of morphogenesis or molecular assembly of S layer protein. 
This work was supported by a Grant-in-Aid for Science Research (no. 62490155) from the Ministry of Education, Science and Culture of Japan.

\section{References}

Baumeister, W., Karrengerg, F., Rachel, R., Engel, A., Ten Heggleler, B. \& Saxton, O. (1982). The major cell envelope protein of Micrococcus radiodurans (RI): structural and chemical characterization. European Journal of Biochemistry 125, 535-544.

Bingle, W. H., DoRaU, J. L. \& PAGE, W. J. (1986). Characterization of the surface layer proteins from Azotobacter vinelandii. Canadian Journal of Microbiology 32, 112-120.

Cleveland, W. W., Fisher, S. G., Kirschner, M. W. \& Laemmli, U. K. (1977). Peptide mapping by limited proteolysis in sodium dodecyl sulfate and analysis by gel electrophoresis. Journal of Biological Chemistry 252, 1102-1106.

Dailey, D. C. \& SChLOEmer, R. H. (1988). Cloning and expression of secreted antigens of Clostridium difficile in Escherichia coli. Infection and Immunity 56, 1655-1657.

KANDLER, O. \& KonIG, H. (1985). Cell envelopes of archaebacteria. In The Bacteria, pp. 413-457. Edited by C. R. Woese \& R. S. Wolfe. London: Academic Press.

Kawata, T., Takeoka, A., Takumi, M. \& Masuda, K. (1984). Demonstration and preliminary characterization of a regular array in the cell wall of Clostridium difficile. FEMS Microbiology Letters 24, 323-328.

Koval, S. F. (1988). Paracrystalline protein surface arrays on bacteria. Canadian Journal of Microbiology 34, 407-414.

LAEMmLI, U. K. (1970). Cleavage of structural proteins during the assembly of the head of bacteriophage T4. Nature, London 227, 680685.

MÜHLPFORDT, H. (1982). The preparation of colloidal gold particles using tannic acid as an additional reducing agent. Experientia 38, $1127-1128$.

Nesbitt, W. E., StaAt, R. H., Rosan, B., Tayor, G. \& Doyle, R. J. (1980). Association of protein with the cell wall of Streptococcus mutans. Infection and Immunity 28, 118-126.
Phipps, B. M., Trust, T. T., Ishiguro, E. E. \& Kay, W. W. (1983). Purification and characterization of the cell surface virulent $A$ protein from Aeromonas salmonicida. Biochemistry 22, 2934-2939.

ROTH, J., BENDAYAN, M.\& ORCI, L. (1978). Ultrastructural localization of intracellular antigens by the use of protein A-gold complex. Journal of Histochemistry and Cytochemistry 26, 1074-1081.

RusSELL, M. W. (1979). Purification and properties of a protein surface antigen of Streptococcus mutans. Microbios 25, 7-18.

SHARP, J. \& POXTON, I. R. (1988). The cell wall proteins of Clostridum difficile. FEMS Microbiology Letters 55, 99-104.

Sleytr, U. B. \& Messner, P. (1983). Crystalline surface layers on bacteria. Annual Review of Microbiology 37, 311-339.

SLEYTR, U. B. \& MESSNER, P. (1988). Crystalline surface layers in procaryotes. Journal of Bacteriology 170, 2891-2897.

Sleytr, U. B., Messner, P., Sara, M. \& Pum. D. (1986). Crystalline envelope layers in archaebacteria. Systematic and Applied Microbiology 7, 310-313.

SMITH, J. (1986). Protein surface layers of bacteria. In Bacterial Outer Membranes as Model System, pp. 343-376. Edited by M. Inouye. New York: John Wiley.

TAKUMI, K., KINOUCHI, T. \& KAWATA, T. (1979). Isolation and partial characterization of exosporium from spores of a highly asporogenic mutant of Clostridium botulinum type A. Microbiology and Immuno$\log y$ 23, 443-454.

Takumi, K., Takeoka, A. \& Kawata, T. (1983). Purification and characterization of a wall protein antigen from Clostridium botulinum type A. Infection and Immunity 39, 1346-1353.

Takumi, K., Takeoka, A. \& Kawata, T. (1987). Purification and immunochemical properties of a wall protein antigen from Clostridium difficile ATCC 11011. Microbiology and Immunology 31, 837849.

Towbin, H., Staehelin, T. \& Gordon, J. (1979). Electrophoretic transfer of proteins from polyacrylamide gels to nitrocellulose sheets: procedure and some applications. Proceedings of the National Academy of Sciences of the United States of America 76, 4350-4354.

TsuboI, A., Tsukagoshi, N. \& UdaKa, S. (1982). Reassembly in vitro of hexagonal surface arrays in a protein-producing bacterium, Bacillus brevis 47. Journal of Bacteriology 151, 1485-1497. 